\title{
PENGUATAN NILAI KARAKTER MAHASISWA BARU BERBASIS PEMBELAJARAN REFLEKTIF (REFLECTION LEARNING)
}

\author{
Muhammad Rais ${ }^{1}$, Badaruddin Anwar ${ }^{2}$, Farida Aryani ${ }^{3}$ \\ ${ }^{1}$ Ahli Teknologi Pembelajaran, Fakultas Teknik Universitas Negeri Makassar \\ raismisi@gmail.com \\ 2Ahli Pedidikan Teknologi Kejuruan, Fakultas Teknik Universitas Negeri Makassar \\ badaruddinanwar@yahoo.co.id \\ 3Ahli Psikologi Pendidikan, Fakultas Ilmu Pendidikan Universitas Negeri Makassar \\ faridayani77@gmail.com
}

\begin{abstract}
This research is a development which will be implemented over two years (2015-2016). Activities of the first year (2015) begins with the start of the new students to analyze characters. The results show that 1) students generally interpret the violence that led to the brawl as anti-social behavior that is unlawful, unethical and needs to be reduced through early preventive approach, 2) is generally of the students know that the brawl behavior both in terms of symptoms, mode, group actors, and sometimes time-period brawl, 3) generally students understanding that prevention brawl can be done through the establishment of anti-violence movement on campus. In the first year has also generated products guide book character building new students through reflective learning model that has been validated. Furthermore, the product was tested on a group of experts and a group of students to test usability, feasibility, and precision guidance and materials. The results show that the guide books and materials meet the criteria of usefulness, feasibility, and accuracy with an average scoring 3 and 4. The criteria for usefulness in the judgment of experts and students stated that book developed guidelines and giving useful in understanding the concept of prevention brawl early for students new. Stated that the eligibility criteria and guidelines developed book is worth the effort to give the appreciation of the character and spirit of community building anti brawl. The accuracy criteria stated that the guide and developing books have substance content and materials that support personal development, especially the development of character values based on the integration of reflective learning, especially learning model.
\end{abstract}

Keywords: Reflective learning, character value, Violence

\begin{abstract}
ABSTRAK
Penelitian ini adalah penelitian pengembangan yang akan dilaksanakan selama dua tahun (20152016). Kegiatan tahun pertama (2015) diawali dengan menganalisis karakter awal mahasiswa baru. Hasilnya menunjukkan bahwa 1) mahasiswa umumnya memaknai kekerasan yang berujung tawuran sebagai perilaku anti sosial yang melanggar hukum, tidak beretika dan perlu direduksi melalui pendekatan preventif awal, 2) umumnya mahasiswa mengetahui bahwa perilaku tawuran baik dari segi gejala, modus, kelompok pelaku, dan kadang waktu-waktu terjadinya tawuran, 3) pemahaman pada mahasiswa bahwa upaya pencegahan tawuran dapat dilakukan melalui pembentukan gerakan anti kekerasan di kampus. Pada tahun pertama juga telah dihasilkan produk buku panduan dan materi pembinaan nilai-nilai karakter mahasiswa baru melalui model pembelajaran reflektif yang telah tervalidasi. Selanjutnya produk diuji pada kelompok ahli dan kelompok mahasiswa untuk menguji kegunaan, kelayakan, dan ketepatan panduan dan materi. Hasilnya menunjukkan bahwa buku panduan dan materi memenuhi kriteria kegunaan, kelayakan, dan ketepatan dengan rata-rata memberi skor 3 dan 4. Kriteria kegunaan menurut penilaian ahli maupun mahasiswa menyatakan bahwa panduan dan buku yang dikembangkan berguna dalam memberi pemahaman konsep pencegahan tawuran sejak dini bagi mahasiswa baru. Kriteria kelayakan dinyatakan bahwa panduan dan buku yang dikembangkan adalah layak dalam upaya memberi penguatan nilai karakter dan semangat membangun komunitas anti tawuran. Kriteria ketepatan dinyatakan bahwa panduan dan buku yang dikembangkan memiliki substansi isi dan materi yang memberi dukungan pengembangan kepribadian khususnya pengembangan nilai-nilai karakter berbasis pada integrasi model pembelajaran khususnya pembelajaran reflektif.
\end{abstract}

Kata Kunci: Pembelajaran Reflektif, Nilai Karakter, Anti Kekerasan. 


\section{PENDAHULUAN}

Pembelajaran merupakan suatu upaya membelajarkan peserta didik, guna menyiapkan generasi pelanjut pembangunan di masa yang akan datang. Fakultas Teknik Universitas Negeri Makassar (FT UNM) sebagai salah satu perguruan tinggi pencetak calon guru vokasi menyiapkan mahasiswa calon sarjana yang akan mengabdikan diri sebagai guru professional dengan tingkat penguasaan bidang studi dan aspek pedagogis yang memadai. Selain itu, sarjana tersebut diharapkan selama menempuh ilmu di bangku kuliah diharapkan mendapatkan pengalaman belajar yang memadai untuk dapat berkompetisi meraih prestasi dan kesuksesan belajar. Kesuksesan dalam belajar di perguruan tinggi dapat diraih selain ditentukan oleh faktor internal dari dalam diri sendiri, juga dipengaruhi oleh lingkungan sebagai faktor eksternal dalam menjalankan proses asimilasi belajar. Salah satu faktor eksternal lingkungan belajar yang dirasakan sangat besar pengaruhnya adalah masalah tawuran. FT UNM dalam beberapa waktu terakhir ini mengalami beberapa kali tawuran antar mahasiswa. Berbagai analisis terhadap penyebab dan solusi penyelesaian telah dilakukan. Ada yang menerapkan sanksi skorsing akademik terhadap mahasiswa pelaku tawuran, bahkan yang lebih keras adalah sanksi DO.

Model pembelajaran reflektif diterapkan atas asumsi bahwa pembelajaran sebagai proses membelajarkan peserta didik, termasuk mahasiswa, merupakan metode yang efektif dalam menanamkan pengetahuan, sikap dan keterampilan. Boud (1989); Degeng (1998); dan Hovermill (2008) menjelaskan bahwa refleksi sebagai kegiatan intelektual dan afektif dimana individu-individu terlibat dalam upaya mengeksplorasi pengalaman dalam rangka mencapai pemahaman dan apresiasi-apresiasi berbasis nilai dengan setumpuk komponen pendukung yang melingkupinya seperti nilai-nilai, adat dan tradisi dalam kehidupan. Dalam konteks ini, pembelajaran reflektif berarti pembelajaran yang memberikan kesempatan kepada setiap orang, termasuk mahasiswa untuk dapat mengekspresikan diri berdasarkan pengalaman nilai yang berlaku dan dianut guna memenuhi standar nilai yang berlaku dalam suatu komunitas.

Dosen dan mahasiswa merupakan pebelajar dan pembelajar yang dapat bersinergi langsung untuk turut berperan mereduksi tawuran di kampus, khususnya di FT UNM. Salah satu model intermedia keduanya adalah melalui pembelajaran. Sampai saat ini, pendekatan pembelajaran belum secara maksimal dilakukan untuk menanamkan nilai dan etika hidup harmonis dalam kampus, terutama mahasiswa pada tahun-tahun awal perkuliahan. Pendekatan pencegahan masih sebatas memberi nasehat sebelum pembelajaran dimulai. Sungguh bahwa pendekatan ini belum optimal menjawab kondisi dan permasalahan melalui pembelajaran. Memandang bahwa integrasi pembelajaran merupakan pendekatan yang efektif dan mudah dilakukan untuk menyampaikan pesan dan peran diri yang positif dalam mengelola diri dan lingkungan, maka upaya pencegahan dan penguatan sikap sosial pada mahasiswa dapat terus dilakukan melalui model-model pembelajaran yang terencana dan sistematis. Salah satu model pembelajaran yang efektif memberikan rasa kesadaran dan refleksi diri yang positif dengan orang lain dan lingkungan adalah pembelajaran reflektif

Pembelajaran reflektif didefinisiakan sebagai pembelajaran yang memberikan kesempatan pada peserta didik untuk berpikir secara reflektif terhadap fenomena dari setiap bidang yang dikaji, mencari akar hubungan untuk memproyeksikan masa depan yang nyata dan rasional (Graham, 2010). Pandangan yang lebih spesifik hubungannya dengan pembelajaran dikemukakan oleh Maine dalam Boud (1989); Kolb (1984); Safery \& Duffy (1996); dan Degeng (1998) yang melihat pentingnya refleksi bagi pengembangan keterampilan-keterampilan belajar, sebagai bagian penting dari proses pembelajaraan berbasis pengalaman, yang merefleksikan kesadaran metakognitif, yaitu kesadaran akan pikiran sendiri sebagaimana tampak dalam cara seseorang mengerjakan tugas tugas dan penggunaan kesadaran diri untuk mengendalikan hal-hal yang akan dikerjakan.

Melalui proses berpikir reflektif, mahasiswa belajar memposisikan diri, mengenali diri, dan mengenali orang lain dan lingkungan sekitar. Proses belajar selanjutnya adalah, mahasiswa membiasakan diri dalam melatih kematangan emosi agar lebih mudah mengelola sikap dan perilaku, termasuk sikap agresif yang positif seperti; semangat yang tinggi, penuh inovasi, dan kreatifitas. Salah satu sebab mengapa mahasiswa FT UNM mudah mela- 
kukan kekerasan dan tawuran antar mahasiswa adalah karena lemahnya sikap refleksi tadi, seperti kurang peka, kurang mengenal dirinya dan orang lain menjadikan mudah menyerang orang lain tanpa memilah substansi dan akar permasalahan. Pendek kata berpikir reflektif tidak menjadi budaya yang dibiasakan oleh mahasiswa dalam menelaah setiap permasalahan, memudahkan mereka terprofokasi untuk melakukan tindakan kekerasan.

Permasalahan tersebut dapat direduksi secara perlahan-lahan dengan pendekatan pembelajaran reflektif, yang memiliki beberapa keistimewaan untuk diterapkan, seperti diungkapkan Drost (2001) sebagai berikut 1) pembelajaran reflektif memungkinkan pembelajar (dosen) untuk memperkaya baik isi maupun susunan bahan pelajaran, 2) pembelajaran reflektif memungkinkan pebelajar (mahasiswa) dapat belajar lebih aktif dan bertanggung jawab, 3) pembelajaran reflektif memungkinkan pebelajar menghubungkan bahan pelajaran dengan pengalaman mereka dan belajar dari pengalaman hidup mereka, di rumah, dunia teman sebaya, dan di masyarakat, 4) membangun kepekaan nurani terhadap hubungan-hubungan manusiawi, sehingga membuat pebelajar semakin peduli dan mengerti terhadap sesama pebelajar lainnya

Sebenarnya, upaya mengurangi tawuran di FT UNM, dapat dicegah secara perlahan-lahan dengan menanamkan pembinaaan sikap harmonisasi lebih dini. Mahasiswa baru sebagai warga baru yang berada di kampus perlu dibekali pendidikan agar dapat meningkatkan sikap harmonis yang tinggi sesama mahasiswa. Salah satu pendidikan tersebut adalah pendidikan karakter yang terintegrasi ke dalam setiap matakuliah. Pendidikan karakter yang diberikan ke mahasiswa tidak diajarkan layaknya matakuliah lainnya, namun dilatihkan dan dipraktekkan kedalam kehidupan kampus.

Istilah pendidikan karakter berasal dari kata nation dan character building. Dalam Rencana Aksi Nasional Pendidikan Karakter (2010), pendidikan karakter disebutkan sebagai pendidikan nilai, pendidikan budi pekerti, pendidikan moral, dan pendidikan watak (Kemendiknas, 2010). Tujuannya adalah mengembangkan kemampuan merumuskan ide, gagasan dan keputusan dengan tetap menjaga nilai-nilai karakter yang baik maupun buruk. Artinya siapapun yang mempelajari nilai-nilai karakter, dapat menanamkan kebiasaan (habituation) secara kontinyu dan mempraktikkan dalam kehidupan sehari-hari.

Nilai-nilai karakter yang dimuat dalam pendidikan karakter meliputi nilai religius, jujur, toleransi, disiplin, kerja keras, kreatif, mandiri, demokratis, rasa ingin tahu, semangat kebangsaan, cinta tanah air, menghargai prestasi, bersahabat/komunikatif, cinta damai, gemar membaca, peduli lingkungan, peduli sosial, dan tanggung jawab, (Kemdiknas, 2010). Samami (2011), menegaskan bahwa nilai-nilai karakter manusia meliputi sistem komponen pengetahuan, kesadaran, kemauan, dan tindakan untuk melaksanakan nilai-nilai baik terhadap Tuhan, diri sendiri, sesama, lingkungan, maupun bangsa. Sementara Pala (2011) mengemukakan bahwa nilai karakter dapat berupa gerakan nasional dalam penciptaan nilai-nilai etika seperti: peduli, kejujuran, tanggung jawab, keadilan, dan menghormati diri dan orang lain.

Nilai-nilai karakter merupakan inti perilaku yang dapat diamati dan dipraktikkan dalam kehidupan sehari-hari. Penerapan nilainilai karakter baik di sekolah, di kampus maupun dalam lingkungan secara umum, dapat dilakukan melalui proses pembelajaran yang menyenangkan formal maupun tidak formal, pembiasaan, figur keteladanan, pembinaan disiplin, hadiah dan hukuman Astuti (2011); Pala (2011); Zubaedi (2011); Buchori \& Setyawati (2015).

Dengan demikian, tujuan penelitian ini adalah menghasilkan model pembelajaran refleksi diri bagi mahasiswa baru yang efektif ditahun awal perkuliahan agar memperoleh semangat rasa cinta damai, tidak mudah terprofokasi, dan anti tawuran. Sebagai kegiatan awal, penelitian ini menekankan pada analisis karakter awal mahasiswa baru terhadap sikap dan pemahaman terhadap kekerasan dalam kampus, hingga diperoleh panduan dan materi produk pembinaan karakter mahasiswa melalui integrasi model pembelajaran reflektif yang berguna, tepat, dan layak.

\section{METODE PENELITIAN}

Penelitian ini merupakan penelitian pengembangan yang dirancang untuk menghasilkan produk. Prosedur penelitian dan pengem-bangan model Borg \& Gall (2003), pada dasarnya terdiri dari tiga fokus utama penelitian, yaitu 1) menganalisis sikap dan 
karakter awal mahasiswa baru, 2) mengembangkan produk berupa panduan dan materi penanaman nilai karakter, 3) menguji keefektifan produk dalam mencapai tujuan. Fokua pertama mengarah pada analisis awal terkait kondisi dan kebutuhan model penanaman nilai karakter dalam upaya menumbuhkan sikap anti kekerasan dan mencegah tawuran. Fokus kedua mengarah pada pengembangan terhadap suatu produk dan fokus ketiga mengarah pada validasi produk, hingga diperoleh produk yang sesuai dengan kebutuhan. Sikap dan karakter awal mahasiswa baru merupakan gambaran awal yang menunjukkan potret dan profil nilai karakter yang sudah dimiliki mahasiswa baru. Panduan dan materi penanaman nilai karakter merupakan perangkat acuan yang memuat petunjuk umum dan petunjuk khusus cara melaksanakan penanaman nilai karakter berbasis pembelajaran reflektif. Sedangkan materi penanaman nilai karakter merupakan perangkat materi nilai-nilai karakter yang memuat tujuan dan jenis materi nilai karakter. Materi ini meliputi: 1) membangun sikap kepedulian (empati antar sesama mahasiswa), 2) mengem-bangkan sikap belajar positif di perguruan tinggi, 3) membangun etika pergaulan kampus yang harmonis, 4) mengenali dan mengatasi potensi konflik dan sikap tanggap, dan 5) membangun sikap anti kekerasan melalui pemberdayan potensi IQ, EQ, dan SQ di kampus.

Panduan dan materi yang efektif adalah panduan dan materi yang sudah tervalidasi sehingga memenuhi aspek kegunaan, aspek ketepatan, maupun aspek kelayakan. Ketiga aspek divalidasi oleh ahli dibidangnya masing-masing dengan menggunakan instrumen validasi ahli.

Model penelitian pengembangan Borg \& Gall (2003) yang diadopsi dengan model Dick \& Carey (2001) secara rinci memiliki lima tahap, yaitu: analisis kebutuhan, desain, pengembangan, evaluasi, dan implementasi yang sebenarnya merupakan tahap pengembangan ADDIE seperti dalam Gambar 1 berikut:

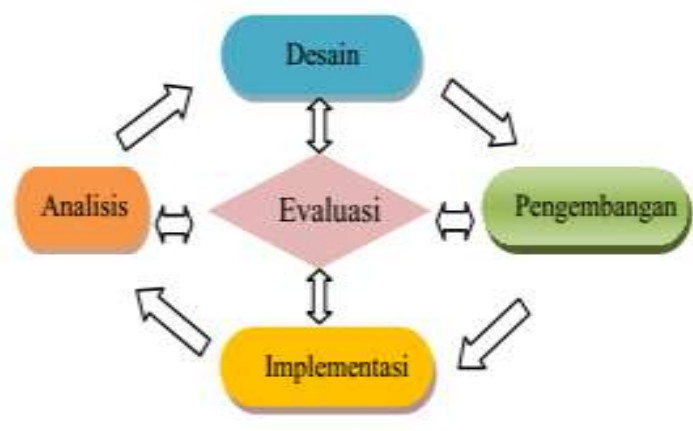

Gambar 1. Desain Pengembangan ADDIE

\section{Tahap 1: Analisis}

Tahap ini dilakukan dengan menganalisis kebutuhan melalui kajian pustaka yang berkaitan dengan topik penelitian, kajian penelitian yang relevan dengan bidang yang diteliti, selanjutnya melakukan studi lapangan yang berkaitan dengan topik penelitian. Model pengembangan Borg \& Gall (2003) mengembangkan daftar kriteria yang dapat dipertimbangkan dalam phase analisis kebutuhan, antara lain 1) apakah produk yang diusulkan sudah disesuaikan dengan kebutuhan, 2) apakah tersedia kajian yang cukup yang memungkinkan produk ini dibangun, 3) apakah tersedia sumber daya manusia, 4) dapatkah produk dikembangkan dalam suatu waktu yang layak.

\section{Tahap 2: Desain}

Tahap ini dilakukan dengan mendesain pembelajaran model pembelajaran reflektif dengan menggunakan desain pengembangan Dick \& Carey (2001), mulai dari tahap analisis hingga tahap menyusun skenario pembelajaran reflektif. Pada tahap ini dilakukan identifikasi nilai karakter pembentuk anti kekerasan yang akan dimasukkan sebagai materi dalam buku panduan pembinaan mahasiswa baru dan menyusun strategi pembelajaran berdasarkan model pembelajaran reflektif (instructional strategy). Berdasarkan draft desain dan draft materi nilai karakter, maka dikembangkan produk berupa model pembinaan, panduan, dan materi nilai-nilai karakter pembentuk anti kekerasan bagi mahasiswa baru.

\section{Tahap 3: Pengembangan}

Pada tahap ini dilakukan pengembangan produk untuk menghasilkan produk berupa model pembinaan kader anti kekerasan menggunakan 
pembelajaran reflektif. Model produk yang dihasilkan pada tahap ini berupa panduan pembinaan nilai-nilai karakter anti kekerasan bagi mahasiswa baru, buku yang memuat materi pembinaan nilai-nilai karakter anti kekerasan bagi mahasiswa. Dalam buku ini memuat format pengamatan dan evaluasi keterlaksanaan implementasi nilai-nilai karakter. Pada tahapan ini diperoleh beberapa video yang dimodifikasi sesuai dengan kebutuhan pembinaan nilai-nilai karakter anti kekerasan bagi mahasiswa baru. Dibagian akhir produk dalam buku, dicantumkan desain outbond bagi mahasiswa baru dalam kerangka gerakan bersama membangun semangat kebersamaan diantara mahasiswa baru dan senior.

\section{Tahap 4: Evaluasi}

Tahap keempat adalah evaluasi terhadap produk yang dikembangkan. Evaluasi dilakukan oleh pakar yang ahli dibidangnya meliputi ahli teknologi pembelajaran dan ahli psikologi pembelajaran. Produk yang sudah divalidasi oleh kelompok ahli selanjutnya dicobakan pada kelompok perorangan maupun kelompok kecil. Aspek yang dinilai meliputi aspek isi, aspek tampilan, dan aspek desain.

\section{Tahap 5: Implementasi}

Tahap akhir dari pengembaangan ini adalah hasil uji coba yang telah direvisi dan dianalisis hingga ditemukan produk akhir yang sudah memenuhi kriteria keefektifan, selanjutnya dilakukan diseminasi produk pada kelompok mahasiswa baru fakultas teknik UNM.

Subjek coba dalam penelitian ini diambil dengan menggunakan purposive sampling sebanyak 30 orang mahasiswa. Data yang digunakan dalam penelitian ini adalah data kuantitatif yang diperoleh dari hasil lembar analisis kebutuhan, lembar ahli materi dan lembar ahli rancangan pembelajaran, serta respon mahasiswa. Data yang diperoleh dari ahli meliputi penilaian ahli isi dan ahli rancangan panduan. Data diperoleh melalui instrumen pengumpul data berupa angket penilaian. Angket dikembangkan untuk mengumpulkan pendapat ahli tentang akseptabilitas panduan dan materi. Aspek-aspek akseptabilitas meliputi aspek kegunaan, ketepatan, dan kelayakan. Masingmasing aspek baik aspek kegunaan, aspek ketepatan, maupun aspek kelayakan memiliki 8 pertanyaan. Setiap pertanyaan memiliki alternatif jawaban berupa nilai skor yang berskala 1- 4 . Setiap angka diberi makna sebagai berikut:

1) tidak berguna/tepat/layak (diberi angka 1),

2) kurang berguna/tepat/layak(diberi angka 2),

3) berguna/tepat/layak (diberi angka 3),

4) sangat berguna/tepat/layak (diberi angka 4).

Jika rentangan penilaian berkisar antara 3

dan 4, maka produk tidak perlu direvisi, kalaupun direvisi hanya sedikit saja demi penyempurnaan produk. Jika rentangan antara 1 dan 2, maka produk direvisi sebagian besar, baik meliputi isi, tampilan, maupun desain.

Ketiga aspek yang meliputi kegunaan, ketepatan, dan kelayakan secara kuantitatif akan dinilai oleh masing-masing kelompok uji coba dengan menggunakan kriteria penilaian sebagai berikut:

Tabel 1: Kriteria penilaian akseptabilitas ketiga aspek (berguna, tepat, dan layak)

\begin{tabular}{|c|c|}
\hline Penggolongan Skor & Kriteria \\
\hline $8,00-<14,00$ & tidak berguna/tepat/layak \\
\hline $14,005-<20,00$ & kurang berguna/tepat/layak \\
\hline $20,00-<26,00$ & berguna/tepat/layak \\
\hline $26,00-32,00$ & sangat berguna/tepat/layak \\
\hline
\end{tabular}

Kriteria penilaian dalam Tabel 1 menunjukkan tingkat kebergunaan, ketepatan, dan kelayakan produk panduan dan materi penanaman nilai karakter berbasis pembelajaran reflektif.

\section{HASIL DAN PEMBAHASAN}

\section{Hasil}

Hasil penelitin tahap pertama ini diperoleh analisis informasi secara persentatif bahwa sebanyak 59,75\% mahasiswa baru menyatakan kesetujuannya memahami tawuran sebelum menjadi mahasiswa baru dan kuliah di UNM. Meskipun 60\% mahasiswa setuju telah mengetahui sejak awal bahwa UNM merupakan kampus yang identitk dengan tawuran, namun pada saat yang sama sebanyak $66 \%$ mahasiswa menyatakan keyakinannya bahwa tawuran di UNM dapat dicegah dengan ikut serta berperan aktif membentuk komunitas anti kekerasan yang dikemas dalam pembelajaran seperti pembelajaran reflektif.

Sebanyak $76.67 \%$ mahasiswa sangat setuju bahwa penyebab terjadinya tawuran karena adanya tekanan dari senior ke junior 
(junior pressure). Meskipun pengaruuh ini seimbang, atara pengaruh postif dan pengaruh negatif yang diberikan, dimana sebanyak $53.33 \%$ menyatakan sangat setuju senior masih mendominasi dari segi jumlah yang mem-berikan pengaruh positif dan $46.67 \%$ yang menyatakan setuju. Jika dideskripsikan secara umum, maka sebanyak 52\% mahasiswa sangat setuju bahwa secara umum pengaruh senior mendominasi dalam memberikan agresi untuk melakukan tindakan kekerasan di kampus yang berujung tawuran.

Sebanyak $63.33 \%$ menyatakan bahwa sikap saling percaya dan menghormati satu sama lain antara senior dan yunior atau sebaliknya diyakini sebagai modal sosial yang baik dalam mencegah kekerasan kampus. Baik mahasiswa senior maupun yunior secara ber-sama-sama sebaiknya bersatu padu membentuk gerakan anti kekerasan di kampus. Hal ini sesuai dengan keyakinan yang dibangun oleh mahasiswa baru yang menyatakan $55.33 \%$ sangat setuju salah satu yang dapat dilakukan mahasiswa dalam mencegah tawuran adalah melalui peran aktif dalam pembentukan gerakan anti kekerasan. Gerakan ini sebanyak $83.33 \%$ yang memandang sebagai gerakan partisipatif yang berjalan berdasarkan sistem dan mekanisme ketahanan terhadap bahaya tawuran melalui sikap tanggap bahaya tawuran.

Untuk dapat menjalankan mekanise ketahanan tersebut, memerlukan pendekatan yang strategis, dan mahasiswa memandang bahwa $53.33 \%$ sangat setuju jika pemberian nilai-nilai gerakan anti kekerasan yang dipandang sebagai nilai karakter anti kekerasan diperoleh melalui integrasi pembelajaran. Pembelajaran nilai karakter anti kekerasan yang dibelajarkan, oleh mahasiswa menyatakan $66.77 \%$ sangat setuju jika pada suatu saat mahasiswa secara sadar sendiri saling memperkuat keyakinan, komitmen, dan mengembangkan nilai empati dan sikap saling menghormati, mereduksi amarah dan emosi dapat dikembangkan dalam proses pembelajaran. Pembelajaran yang coba diintegrasikan adalah pembelajaran refleksi, yaitu pembelajaran yang memberikan kesempataan pada mahasiswa untuk merefleksikan pengalaman belajar masa lalu, melalui proses berpikir reflektif (analisis konteks, penyajian pengalaman, refleksi, rencana aksi, dan evaluasi). Untuk tujuan ini, sebanyak
54.26\% mahasiswa menyatakan sangat setuju, dan $45.74 \%$ setuju.

Secara umum jika dideskripsikan secara kuantitatif, persentasi ketiga kategori yang meliputi: persepsi awal terhadap tawuran, pemahaman penyebab terjadinya tawuran, dan upaya pencegahan tawuran dapat disajikan dalam tiga indikator tinggi, sedang, dan rendah. Hasil analisisnya disajikan dalam diagram berikut:

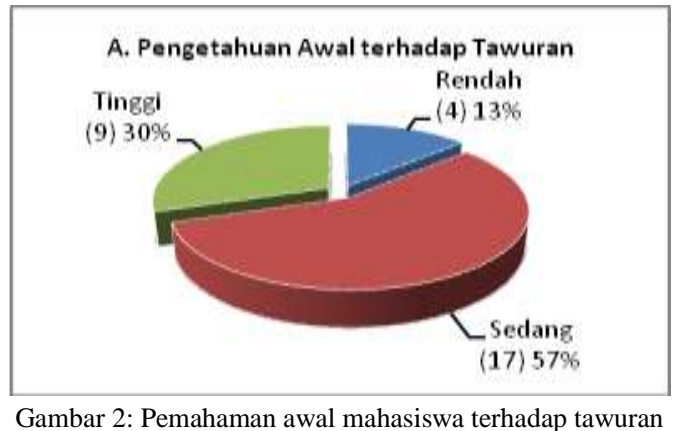

Gambar 1 di atas menunjukkan bahwa umumnya tingkat pengetahuan awal mahasiswa baru terhadap masalah tawuran adalah kategori sedang. Sesuai dengan deskripsi data yang ditampilkan yakni sebanyak 17 orang atau sekitar $56.67 \%$ dari 30 orang memiliki pemahaman yang cukup/sedang terhadap tawuran. Pemahaman ini diperoleh, baik ketika mahasiswa baru duduk di sekolah lanjutan, apakah karena sekolahnya pernah tawuran atau sekolah lain yang tawuran ataupun memperoleh pengetahuan melalui media informasi cetak maupun elektroniik. Pemahaman ini dapat menjadi penduga awal bahwa mahasiswa baru memaknai tawuran kekerasan yang berujung tawuran sebagai perilaku anti sosial yang melanggar hukum, tidak beretika dan perlu direduksi melalu pendekatan preventif awal. Itulah pentingnya memiliki pengetahuan awal terhadap tawuran agar mahasiswa dapat berpikir reflektif memulai dari berpikir: "apa", "mengapa", "jika, maka", "bagaimana" dan "mengapa". Ini adalah kunci untuk memulai refleksi diri. 


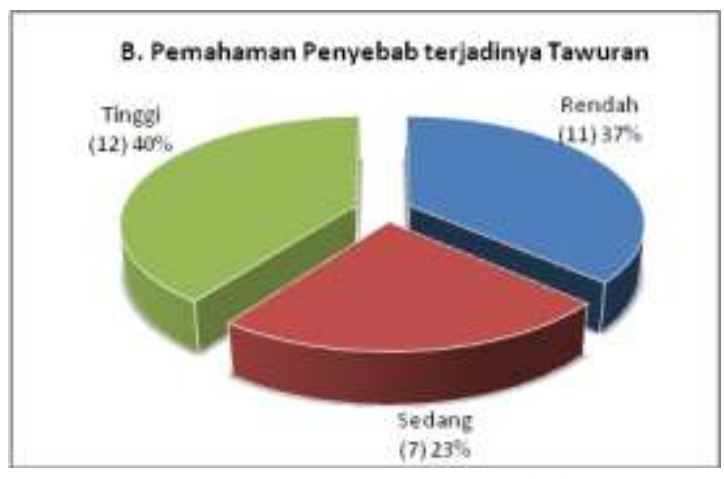

Gambar 3: Tingkat pemahaman penyebab terjadinya tawuran

Tingkat pemahaman mahasiswa terhadap terjadinya tawuran menurut diagram 2 dapat dijelaskan bahwa umumnya mahasiswa memiliki pamahaman yang tinggi yaitu sebanyak 12 orang atau sekitar $40 \%$. Secara kuantitatif, angka ini menjadi umum dan bersifat generatif bahwa umumnya mahasiswa mengetahui perilaku tawuran baik dari segi gejala, modus, kelompok pelaku, dan kadang waktu-waktu terjadinya tawuran. Jika hal ini mampu teridentifikasi dengan baik, maka bukan tidak mungkin pendekatan yang strategis dalam mereduksi tawuran adalah melalui tindakat preventif dengan pemberian penguatan anti kekerasan dan gerakan tidak mudah terprofokasi.

Hal ini sejalan dengan kategori ketiga dari instrumen yang dikembangkan, yaitu upaya pencegahan tawuran melalui pembentukan gerakan anti kekerasan di kampus. Gerakan ini dalam kerangka pencegahan dan penguatan sejak awal pada mahasiswa agar memiliki resistansi yang kuat dalam menghadapi tindakan, ajakan dan profokasi negatif yang berpotensi terjadinya kekerasan yang berujung tawuran.

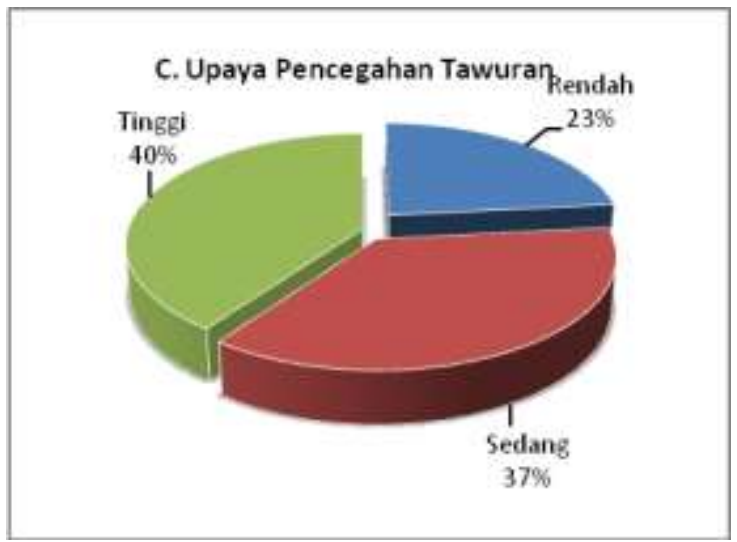

Gambar 4: Upaya pencegahan tawuran

Gambar 3 secara kuantitatif menunjukkan bahwa tingkat pengetahuan mahasiswa terhadap upaya pencegahan tawuran adalah tinggi, yakni sebanyak 12 orang atau sekitar $40 \%$. Angka ini mendeskripsikan bahwa mahasiswa memiliki keinginan yang kuat untuk bersatu padu mereduksi tawuran. Secara bersama-sama mahasiswa ingin mengurangi perilaku kekerasan di kampus maupun luar kampus/masyaraat luar yang sudah sering memprofokasi tindakan kekerasan yang memicu terjadinya tawuran.

Hasil pengembangan teori dan praktek pembinaan nilai karakter mahasiswa yang diperoleh melalui studi focus group discussion $(F G D)$, menujukkan bahwa model penguatan nilai karakter mahasiswa baru yang dibangun dan diintegrasikan melalui pembelajaran reflektif memenuhi validitas, akseptabilitas dan efek-tivitas baik dari penilai ahli maupun dari kelompok uji coba perorangan, terbatas, dan lapangan.

Pembelajaran reflektif sebagai strategi membelajarkan nilai-nilai karakater anti kekerasan bagi mahasiswa baru menggunakan langkah-langkah pembelajaran reflektif. Adapun pelaksanaan pembelajaran dilaksanakan dengan menggunakan langkah-langkah sebagai berikut:

a. Skenario 1: Pengenalan Konteks

Kesempatan untuk berbagi cerita membahas masalah dan mengaitkannya dengan dunia nyata. Belajar pada tahapan mengenal konteks, diawali dengan pertanyaan yang mesugesti pikiran: "who am i", "who we are", "what our problem", "how to solve", dan "let's discuss together". Kalimat pertanyaan ini menjadi kunci mengawali diskusi materi 1 hingga mateir 5. Pada tahapan skenario ini, mahasiswa dibagi dalam beberapa kelompok dengan jumlah anggota yang proporsional. Setiap kelompok menganalisis konteks masalah.

b. Skenario 2: Penyajian Pengalaman

Penyajian pengalaman dilakukan dengan memberi kesempatan mahasiswa untuk berbicara menyampaikan pengalaman belajarnya masing-masing, kesulitan, hambatan, kesuksesan dan peluang menjadi satu kesatuan yang dibahas hingga ditemukan titik temu dan cara pandang yang sama. Pengalaman yang diberikan adalah terkait materi 1 hingga materi 5. Mahasiswa secara berkelompok merumuskan dan menuangkan ide pikiran. Setiap pikiran dari anggota kelompok dituliskan lalu dipetakan inti pikirannya.

c. Skenario 3: Refleksi 
Pada tahap refleksi mahasiswa dikondisikan agar memanfaatkan kemampuan berpikir kritis dalam mengkonstruksi berbagai materi 1sampai materi 5. Refleksi dimulai dengan melontarkan konstruksi pertanyaan seperti: "mengapa?", “apa yang terjadi?", "bagaimana jika?”. Pelaksanaan refleksi dilakukan dimasingmasing kelompok, hasilnya dituliskan dalam kertas flip chart dan ditempelkan di dinding yang akan dipre-sentasikan secara berkelompok. Sebelum presentasi dilakukan sesi galeri walk.

\section{d. Skenario 4: Aksi}

Pada tahap aksi mahasiswa akan banyak melakukan praktek pembelajaran reflektif, belajar berdiskusi, mengutarakan gagasan, ideide cemerlang membahas masalah hingga merumuskan suatu kesimpulan strategis dan konstruktif.

\section{e. Skenario 5: Evaluasi}

Pada tahap evaluasi, mahasiswa dan dosen secara bersama melakukan refleksi kembali yang bersifat menyeluruh untuk melihat perkembangan pemahaman. Menjelaskan hal yang sudah dipahami dan hal yang belum dipahami sehingga yang sudah dipahami perlu dikuatkan, dan yang belum dipahami perlu review ulang dan pengayaan kembali .

Skenario pemembelajaran ini dilakukan setiap perkuliahan berlangsung, dengan mengacu pada prinsip-prinsip pembelajaran aktif. Menempatkan mahasiswa sebagai subyek sekaligus objek pembelajaran. Mahasiswa dikondisikan belajar melakukan penemuan sendiri terhadap konsep-konsep nilai karakter yang sedang dan akan dipelajari.

\section{Pembahasan}

Pembahasan dalam penelitian ini mengacu pada hasil penelitian yang diperoleh. Pembahasan kali ini fokus pada bagaimana membahas sikap mahasiswa baru yang memiliki keinginan kuat dalam mereduksi perilaku kekerasan yang berpotensi terjadinya tawuran di kampus. Sikap ini diilhami oleh teori belajar sosial yang menyatakan bahwa faktor sosial dan kognitif dan perilaku memainkan peranan penting dalam pembelajaran (Slavin, 2000; Santrock, 2007; Salkind, 2008). Menurut Bandura (1999), seseorang mempelajari perilaku tertentu sebagai kebiasaan yang diamati sehingga melahirkan pembiasaan perilaku yang sama dengan yang diamati. Teori ini pertama kali diperkenalkan oleh Neil Miller dan John Dollard pada tahun 1941 yang kemudian dikembangkan oleh Albert Bandura dan Richard Walters pada tahun 1959. Teori belajar sosial Bandura menunjukkan pentingnya proses mengamati dan meniru perilaku, sikap dan reaksi emosi orang lain.

Teori ini menjelaskan perilaku manusia untuk menirukan hal-hal yang baik dalam konteks interaksi timbal balik yang berkesinambungan antara kognitif, perilaku dan pengaruh lingkungan (Bandura, 1999). Dalam pandangannya selanjutnya, Bandura mengemukakan empat faktor yang berproses dalam belajar observasi, yaitu:

1. Perhatian (atensi), mencakup peristiwa peniruan (adanya kejelasan, keterlibatan perasaan, tingkat kerumitan, kelaziman, nilai fungsi) dan karakteristik pengamat (kemampuan indra, minat, persepsi, penguatan sebelumnya).

2. Penyimpanan atau proses mengingat, mencakup pengkodean simbolik, pengorganisasian pikiran, pengulangan simbol, pengulangan motorik.

3. Reproduksi motorik, mencakup kemampuan fisik, kemampuan meniru, keakuratan umpan balik.

4. Motivasi, mencakup dorongan dari luar dan penghargaan terhadap diri sendiri.

Selain itu, Reigeluth (1999) menegaskan, harus diperhatikan bahwa faktor model atau teladan mempunyai prinsip-prinsip sebagai berikut:

1. Tingkat tertinggi belajar dari pengamatan diperoleh dengan cara mengorganisasikan sejak awal dan mengulangi perilaku secara simbolik kemudian melakukannya. Proses mengingat akan lebih baik dengan cara mengkodekan perilaku yang ditiru ke dalam kata-kata, tanda atau gambar daripada hanya observasi sederhana (hanya melihat saja).

2. Individu lebih menyukai perilaku yang ditiru jika sesuai dengan nilai yang dimilikinya.

3. Individu akan menyukai perilaku yang ditiru jika model atau panutan, tersebut disukai dan dihargai dan perilakunya mempunyai nilai yang bermanfaat.

Teori belajar sosial menjadi dasar dari perilaku pemodelan yang digunakan dalam berbagai pendidikan secara massal. Karena melibatkan atensi, ingatan dan motivasi, teori belajar sosial dilihat dalam kerangka teori 
behavior-kognitif. dapat membantu memahami bagaimana memodifikasi perilaku mahasiswa untuk ikut peduli dalam menjaga kampus yang tertib dan damai. Teori pembelajaran sosial membahas tentang (1) bagaimana perilaku dipengaruhi oleh lingkungan melalui penguatan (reinforcement) dan observational learning, (2) cara pandang dan cara pikir yang dimiliki terhadap informasi, (3) begitu pula sebaliknya, bagaimana perilaku mempengaruhi lingkungan dan menciptakan penguat (reinforcement) dan observational opportunity (Bandura, 1999; Salkind, 2008).

Jika teori belajar perilaku Bandura ini diintegrasikan kedalam praktek pembelajaran reflketif, dimana mahasiswa dalam memutuskan setiap langkah yang akan diambil, mengaca pada pada pembelajaran reflektif yang oleh Kolb (2000) menjelaskan bahwa individu belajar melalui pengamatan, penekanannya mengamati sebelum menilai, menyimak suatu perkara dari berbagai perspektif, dan selalu menyimak makna dari hal-hal yang diamati. Dalam proses belajar, individu akan meng-gunakan pikiran dan perasaannya untuk mem-bentuk pendapat, selanjutnya melakukan singkronisasi atas apa yang dipikirkan dan dikatakan dengan apa yang dilakukan untuk ditirukan Baldacchino (2014). Individu akan berkembang dengan mudah jika melalui visualisasi yang diteladankan oleh individu lain yang terlihat melalui peniruan perilaku. Dalam konteks ini, nilai-nilai karakter yang ditum-buhkan dalam lingkungan kampus dapat berkembang menjadi budaya ramah, hingga terbina relasi sosial antar mahasiswa yang damai dan harmonis.

Sejalan dengan konsep Moon (2004); Stroobants, Chambers, \& Clarke (2007); Tannir \& Al-Hroub (2013) yang menjelaskan bahwa belajar mengaplikasikan tindakan dipengaruhi oleh interaksi kelompok, terbangun melalui dialog, percakapan, dan komunikasi sehingga terbentuk komunikasi dan sikap percaya diri yang tinggi dalam membangun konstruksi pengetahuan baru. Sikap ini merupakan sebagai dari keterampilan sosial dalam berkomunikasi. Mahasiswa hanya perlu mengutamakan proses berpikir atas dasar refleksi diri berdasarkan pengalaman masa lalu dan harapan akan masa depan Morrow (2009).

Dalam konteks ini, pembelajaran reflektif memberi kesempatan bagi individu dalam kelompok untuk dapat mengolah pikiran dan informasi ketika akan memutuskan suatu pemikiran (Xie, 2007).

Pembahasan selanjutnya adalah penilaian yang diberikan oleh ahli baik ahli pembelajaran, maupun ahli psikologi pembelajaran, termasuk adalah penilaian yang dilakukan oleh kelompok mahasiswa sebagai pengguna produk. Hasil penilaian yang diberikan oleh ahli pembelajaran maupun psikologi pembelajaran baik pada instrumen, panduan, dan materi penanaman nilai karakter menunjukkan rata-rata nilai baik untuk. Termasuk penilaian oleh kelompok mahasiswa yang menunjukkan ketertarikan pada panduan dan materi yang memiliki kemenarikan dalam membangun nilai-nilai karakter di kampus khususnya di Fakultas Teknik UNM.

Mengacu pada pandangan para tim penilai buku ajar yang dikutip dari Khoirawati (2012) tentang buku teks yang baik hendaknya tidak hanya mengandung unsur intelligent textbook melainkan harus berupa mindful textbook. Buku dengan unsur mindful text dapat berupa buku panduan belajar Putra (2007) yang sifatnya menuntun pembaca. Dijelaskan bahwa buku yang memenuhi unsur mindfull text adalah buku yang memberi informasi dan tuntunan untuk belajar mengkonstruksi pemahaman mulai dari pemahaman tingkat rendah hingga tingkat tinggi. Selain itu, buku mindful text selalu mengaitkan materi kajian dengan lingkungan nyata. Pendapat yang sama dipertegas oleh Tarigan (2009) buku teks yang baik paling tidak: 1) memiliki kemenarikan untuk dibaca, 2) menambah motivasi pembaca (motivational to learn), 3) memuat ilustrasi gambar yang sesuai, 4) menstimulasi perasaan pembaca untuk mengaitkan antara hal yang dibaca, dipikirkan dan dilakukan (meaningfull), 5) materinya memberikan kesempatan pada pembaca untuk dapat belajar mandiri (self study) dan saling menghargai antar pribadi.

Pikiran-pikiran yang dijelaskan di atas, memberikan keyakinan yang kuat bahwa buku yang baik adalah yang bermanfaat dan memiliki nilai-nilai pengetahuan, sikap dan keterampilan dalam membangun kehidupan. Berdasarkan hal itu, maka panduan dan materi penanaman nilainilai karakter sebagai suatu buku yang intellegence text sekaligus mindful text, dapat sesegara mungkin diterapkan bagi pengembangan pembinaan kemahasiswaan dikampus, khususnya di Universitas Negeri Makassar dengan memaksimalkan dukungan lembaga, 
dosen, dan mahasiswa, termasuk masyarakat sekitar kampus.

\section{SIMPULAN DAN SARAN}

Berdasarkan tujuan penelitian yang diajukan dalam penelitian ini, dan dari hasil analisis data dan pembahasan yang dipaparkan, dapat disimpulkan bahwa umumnya mahasiswa memaknai kekerasan yang berujung tawuran sebagai perilaku anti sosial yang melanggar hukum, tidak beretika dan perlu direduksi melalu pendekatan prefentif awal. Selanjutya mahasiswa mengetahui dan memahami bahwa perilaku tawuran baik dari segi gejala, modus, kelompok pelaku, dan kadang waktu-waktu terjadinya tawuran, dapat dicegah melalui pembentukan gerakan anti kekerasan di kampus. Sejumlah nilai karakter yang telah dan akan dikembangkan dalam buku panduan pengembangan karakter anti kekerasan dalam kampus meliputi: 1) Membangun sikap kepedulian (empati antar sesama mahasiswa), 2) mengembangkan sikap belajar positif di perguruan tinggi, 3) membangun etika pergaulan kampus yang harmonis, 4) mengenali dan mengatasi potensi konflik dan sikap tanggap, dan 5) membangun sikap anti kekerasan melalui pemberdayan potensi IQ, EQ, dan SQ di kampus akan diintegrasikan dalam pembelajaran reflektif.

Produk berupa panduan dan buku materi penanaman nilai-nilai karakter berbasis pembelajaran reflektif telah mencapai kriteria valid mencakup aspek kegunaan, ketepatan, dan kelayakan setelah melalui uji coba ahli, uji coba kelompok perorangan dan kelompok kecil. Setelah melalui revisi, produk telah memenuhi aspek akseptabilitas dan dapat digunakan dalam pembinaan nilai-nilai karakter mahasiswa baru sebagaai upaya memberi penguatan sikap anti kekerasan dan mencegah tawuran.

Hal yang dapat disarankan adalah perlunya dikembangkan basis data yang kuat terkait evidence based perilaku kekerasan yang pernah terjadi di UNM. Ini menjadi pintu awal untuk masuk menganalisis permasalahan. Issunya bukan hanya angka-angka kejadian dan jumlah korban, tetapi akan ada report terkait faktorfaktor penyebab, gejala yang mengawali kejadian, serta model penanganan kasus yang dilakukan. Selama ini yang dilakukan secara umum adalah menutup akses kekerasan secara langsung melalui: 1) isolasi akses jalan (yang terbukti belum efektif) dan menghentikan perkuliahan sementara setiap ada tindakan kekerasan yang berujung tawuran (efektif untuk sesaat, sewaktu-waktu dapat berulang sebagai tindakan/aksi balasan). Jika kemudian ada alternatif lain selain yang telah dilakukan selama ini, maka pendekatan preventif secara sistematis dan kontinyu setiap tahun adalah melalui penguatan sikap anti kekerasan melalui penanaman nilai karakter bagi mahasiswa baru berbasis pembelajaran reflektif.

\section{DAFTAR RUJUKAN}

Astuti, Danik. 2011. Pembinaan Karakter pada Siswa Kelas VII di SMP Negeri 2 Secang Kabupaten Magelang. Skripsi Online. Universitas Negeri Semarang. http://lib.unnes.ac.id. Diakes Selasa tanggal 12 Januari 2015.

Baldacchino, John. 2014. John Dewey Liberty and the Pedagogy of Disposition. New York London. Springer Dordrecht Heidelberg

Bandura, A. 1999. Social Learning Theory. Prentice Hall. New Jersey

Borg, Walter R. \& Gall, D. Meredith., 2003. Education Research:an Introduction. $\left(7^{\text {th }}\right.$ Edition). Allyn Bacon

Boud, D., Keogh, R. \& Walker, D. Promoting Reflection in Learning: a Model, dalam David Boud et. all (Ed).1989. Reflection: Turning Experience into Learning. London: Kogan Page.

Buchori, Achmad \& Setyawati, Rina Dwi. 2015. Development Learning Model of Charactereducation Through E-Comic In Elementary School. International Journal of Education and Research. Vol. 3 No. 9 September 2015. ISSN: 2411-5681. Page. 369-386. (Online) diakses Selasa 12 Januari 2015. www.ijern.com

Degeng, I.N.S. 1998. Mencari Paradigma Baru. Pemecahan masalah Belajar. Dari Keteraturan Menuju ke Kesemrawutan. Pidato Pengukuhan Pengajar Besar IKIP Malang; Malang: IKIP Malang

Dick, Walter and Carey, Lou. 2001. The Systematic Design of Instruction. ${ }^{4 t h}$ edition. New York. Longman

Drost, J. 2001. Ignatian Pedagogy: A Practical Approach. Jakarta. 
Graham, G., Holt/Hale, S.A., and Parker, M. 2010. Children moving: a reflective approach for teaching physical education. 8 th ed. Boston: Mc Graw Hill.

Hovermill, J., Crites, T. 2008. Integrating Content, Pedagogy, and Reflectiv Practice: Innovative New Distance Learning Courses and Programs for Mathematics Teachers. Online Journal of Distance Learning Administration

Kemendiknas. 2010. Pengembangan Pendidikan Budaya dan Karakter Bangsa: Pedoman Sekolah. Jakarta.

Khoirawati. 2012. Tentang Buku Ajar. https://khoirawatidempo.wordpress.com/2 012/03/13/tentang-buku-ajar/\#_ftn22. Diakses pada tanggal 12 September 2015.

Kolb, D.A. 1984. Experiential Learning: Experience as The Source of Learning and Development. New Jersey. Prentice Hall, Inc.

Kolb, D.A \& Boyatzis, R.E. 2000. Experiential Learning Theory: Previous Research and New Directions, (Online), (http://.d.umn.edu/ kgilbert/educ5165/exp eriential-learning-theory.pdf), diakses 30 Agustus 2010.

Moon, J. 2004. A handbook of reflective and experiential learning: Theory and practice. Abingdon, England: Routledge Farmer

Morrow, Elizabeth. 2009 Teaching Critical Reflection in Healthcare Professional Education. Higher Education Research Network Journal Prizewinning Essays. King's Learning Institute. King's College London. Vol.1 (2009): 13-23

Pala, Aynur. 2011. The Need For Character Education. International Journal Of Social Sciences And Humanity Studies Vol 3, No 2, 2011 ISSN: 1309-8063 (Online) diakses Selasa $\quad 12 \quad$ Januari 2015. http://www.sobiad.org/ejournals.

Putra. R Masri Sareb. 2007. How to Write Your Own Text Book Cara Cepat dan Asyik Membuat Buku Ajar yang Powerful. Bandung : Kolbu

Reigeluth. M. Charles. 1999. Instructional-Design Theories and Models. Volume II. London. Lawrence Erlbaum Associates Publisher.
Salkind, J. Neil. 2008. Encyclopedia of Educational Psychology. United States of America. Sage Publications.

Samani, Muchlas dan Hariyanto, 2011. Konsep dan Model Pendidikan Karakter. Bandung: PT. Remaja Rosdakarya

Santrock, J.W. 2007. Psikologi Perkembangan. Edisi 11 Jilid 1. Jakarta: Erlangga

Safery, J.R. \& T.M. Duffy. 1996 Problem Based Learning: An Instructional Model and Its Constructivist Framework dalam Brent G. Wilson (ed) Constructivist Learning Environment; New Jersey: Educational Technology Publications.

Slavin, Robert E. 2000. Educational Psychology Sixth Edition. Boston: Allyn and Bacon

Stroobants, H, Chambers, P \& Clarke, B. 2007. Reflective Journeys: A Fieldbook for Facilitating Life-Long Learning in Vocational Education and Training Rome: Leonardo da Vinci REFLECT Project.

Tannir, Abir \& Al-Hroub Anies. 2013. Effects Of Character Education On The SelfEsteem OfIntellectually Able And Less Able Elementary Students In Kuwait. International Journal of Special Education Vol 28, No: 2, 2013. (online) diakses Selasa 12 Januari 2015. http://www.internationalsped.com/docum ents/Character_Education_Manuscript $\% 2$ 0_\%20formatted.docx

Tarigan. Djago. 2009. Telaah Buku Teks Bahasa Indonesia. Bandung. Angkasa

Xie, Ying., Ke, Fengfeng., Sharma, Priya. 2007. The effect of peer feedback for blogging on college students' reflective learning processes. Internet and Higher Education. 11 (2008) 18-25.

Zubaedi. 2011. Desain Pendidikan Karakter Konsepsi dan Aplikasinya dalam Lembaga Pendidikan. Jakarta: Kencana Prenada Media Group 